\title{
The twisting and (re)connecting of conducting research during COVID-19
}

Jing Jin

Department of Elementary Education, University of Alberta

\section{Abstract}

This presentation is driven from my on-going doctoral research on examining the use of children's literature in English-Chinese bilingual education in the Canadian context. However, instead of demonstrating some potential findings and implications, it more focused on my experience of the twisting and (re)connecting in the process of conducting the research during the pandemic of COVID-19. Underpinned by sociocultural perspectives on literacy (Kress 2000; New London Group 1996; Perry 2012; Unrau and Alvermann 2013), and the continua of biliteracy (Hornberger and Skilton-Sylvester 2003), my research first examined what type of children's literature that teachers and parents often or prefer to use with bilingual children. Secondly, it investigated what role children's literature plays in bilingual children's language and literacy development. Finally, it explored how teachers' and parents' experiences and perspectives with children's literature may impact their pedagogical practices in bilingual education.

Due to the impact of COVID-19, I have to amend my research in order to conform to schools' and districts' policies as well as individual participant's need. In this process, I have encountered various unexpected twisting that hinder the research but also (re)connecting which shed new light on my ongoing research. Despite I have to redesign my research methods and broaden the scope of participants, I am able to make (re)connections with broader communities and through which new possibilities and inquires emergent. For example, because I changed to do the interviews in remote ways, I was able to reconnect with some of the Chinese teachers and parents I knew. Since it was impossible to get enough participants from the bilingual program, I extended the scope to broader bilingual education. In this way, I can include more educators who are working in the field. By talking with more educators and parents I realized that we have common concerns on children's reading and literacy development during the COVID-19.

The twisting and (re)connecting also provided me an opportunity to re-examine the theoretical frameworks. The pandemic made most of the reading activities have to go online, and the shortcomings of using and sharing Chinese children's literature have been amplified because the transition was not as smoothly as English children's literature. It demonstrates that societal power structure has largely impacted both the accessibility and utility of Chinese children's literature in Western Canada. This situation makes me better understand when Hornberger and Skilton-Sylvester (2003) indicated, although some actors and practices at the traditionally powerful ends of the continua of biliteracy might currently be privileged, they need not be. Instead, as they suggested, "the very nature and definition of what is powerful biliteracy is open to transformation through what actors-educators, researchers, community members, and policy makers-do in their everyday practices" (pp. 38-39).

\section{Reference:}

Hornberger, NH, Skilton-Sylvester, E. 2003. Revisiting the continua of biliteracy: international and critical perspectives. In: Hornberger NH, editor. Continua of biliteracy: an ecological framework for educational policy, research, and practice in multilingual settings. Clevedon: Multilingual Matters. p. 35-67. Kress, G. 2000. Multimodality. In: Cope B, Kalantzis M, editors. Multiliteracies: literacy learning and the design of social futures. London: Routledge. p. 182-202. New London Group. 1996. A Pedagogy of multiliteracies: designing social futures. Harvard Educational Review, 66(1): 60-92.Perry, KH. 2012. What is literacy? A critical overview of sociocultural perspectives. Journal of Language and Literacy Education, 8(1): 50-71.Unrau, NJ, Alvermann, DE. 2013. Literacies and their investigation through theories and models. In: Alvermann DE, Unrau NJ, Ruddell RB, editors. Theoretical models and processes of reading. Newark(DE): International Reading Association. p. 47-90.

Cite as: Jin J. 2021. The twisting and (re)connecting of conducting research during COVID-19. Alberta Academic Review, Vol 4 (1): 5, EEGSA-SEGSA Special Issue: Remote Connections, DOI: 10.29173/aar124 